\begin{tabular}{ll}
\hline 論 & 説 \\
\hline
\end{tabular}

\title{
耳鼻咽喉科を支えるもの
}

\author{
鈴木淳 一

\section{Supportive Factors in Otorhinolaryngology}

\author{
Jun-Ichi Suzuki \\ (Teikyo Univ.)
}

The raison d'etre of a clinical department is to provide effective care., i. e. medicine is based on social needs. Otorhinolaryngology is in no way an exception. Medical care as well as medical sciences are making continual and rapid progress, particulary during the last several decades. One problem with such rapid progress in medicine is an efficient application of the results. More effective and specific strategies have to be devised, probably in a fashion similar to those used in modern technology. In otorhinolaryngology, at least three important areas have shown outstanding progress - diagnostic electronics, microsurgical techniques, and speech hearing rehabilitation. These three provide typical examples of how advances in medicine can fall short of being optimally applied. Socioeconomic, political as well as educational considerations are indispensable for surmounting these difficulties.

\section{1.はじめに}

臨床科の支えはすぐれた治療である，家族など，身近に病人がでるとすぐわかるととは，その方 面の第一者を求める気持ちである. 求めるのは, まず正しい診断であるが, 結局は, 有効な治療法 を求めていることがわかる.

医学は，社会の needs 亿基礎をおいていることは明らかである. 臨床医学は，その求めに応え ることが第一番で，臨床科を支えるものは治療であることが理解される．

臨床教室の活動状態は, しかし, 研究活動によって測定されることが多い. 学会活動は, 研究の 報告が主体をなしており，臨床活動はそてに反影すると信じられているが，乙れは常に正しくはな いというのが筆者の主旨である。

学会活動は, 臨床活動の直接の反影でないのは, 絵画における「具象と抽象」の関係に対比され る. 抽象, すなわち学問のレベルで, 具象, すなわち患者をはなれて, 学問はむしろどんどんと淮 むのが普通であるからである．患者不在の医学の危険が叫ばれる所似であある. 
耳鼻咽喉科領域であ，学会活動は盛んである，学会活動においては，臨床家としての立場，すな わち患者の存在が，ときに忘れられているようなととはないか。 また，実際の臨床に沶いてさえ， こういった患者不在がありはしないか．とのような見地から，わが耳鼻咽喉科臨床を支えるべきも のについて具体的に考えてみた。

\section{2. 進歩と定着のへだたり“150年”をどうする}

耳鼻咽喉科ほど，この30年間に変貌した臨床 科目も少ないのではなかろうか. 変貌の原動力 は, 抗生物質, 電子器械, 基礎医学領域の進歩 の 3 者である.

今を去る 4 年前, 第76回日本耳鼻咽喉科学会 総会が熊本で開かれ，そのシンポジゥムに，

「耳鼻咽喉科領域に打ける進歩と定着」があっ た. 学問は, 主に大学で進歩するはずであるが, 実地臨床は, 大学は一部を分担するに過ぎず, 大部分は開業医師や，大小の病院でおこなわれ ている，診療上の進歩ないし変化が実地に定着 するには時間がかかる．定着を促すためには， メディアが必要であるが，わが国では，学会と， 限られた医師会学術部などの活動があるに過ぎ ない. 雑誌その他の刊行物は, 一部の勉強家に しか有効でない。

大学に 10 年いて35才, 臨床活動のピークにあ
る実地医家の平均が50才とすると，少なくとも この間に15年の開きがあるととになる，最近の 医学の進歩は, とくに速やかで, 今の 1 年は, ひと昔前の 10 年に相当すると，開きは15年では なく150年となる勘定である. 150年は，やや誇 張的であるにしてす，乙の開きが存在するとい う重大性と，乙の開きを埋める困難性に，いさ さかのうろたえを感じないわけにゆかない，昔 の方法が，あちろんすべて悪いわけではない． 臨床では，しかし，常に，今日，もっとも良い と思われる方法を応用すべきであるとすれば， “150年のおくれ”は大きすぎる，ての進歩と定 着の隔りを出来るだけ縮少するためには，多く の異ったアプローチが必要であるように思われ る．学問上の進歩をただ知識として伝達するの みでは, 問題解決の一部にしか役立たないとと を知っている必要むある。

\section{3 . 進歩の臨床定着に必要な方策を模索}

いわゆる生涯教育が唱えられて久しいが，わ が国に拈けるそれが，多くの人々の努力にも拘 らず，すべての領域で，すべての人々にたいし て有効であったとは考えられない。

わが国の生涯教育は，すべての医師を対象と するむのではむちろんないし，方法論的にも， 講演会などで，受け身に知識伝達のみを行うも のが大部分である。はじめから，十分な効果を 期待していない，いわば敗北主義があると疑わ れてあ仕方がない.

医学, 医療上の進歩を診療上に具体化するた めには，そむそも，単に医師に新しい知識を伝 達すればよいとする考えに誤りがあるのではな かろうか。例をあげれば限りがない，複雑な最 近の聴覚検査には, 高価な電子機械ばかりでは
なく，それを駆使する専門の検査技師が必要で ある。”また，少くとあ 2 人以上の術者を必要と する手術が多いのに，ソロ・プラクティスは不 都合である．幼児難聴には，診断のみでなく， 実際に指導し訓練するヒトと，それを働かせる システムが必要である．現在の健保制度にもそ の要望にあわせての変革が必要である.

すなわち，てのように， $2 \cdot 3$ の例をあげて あすぐわかることは，今日の要求や医学の進歩 を具体化するためには，その知識の普及に加え て，システムにまつわる人的，物的，すべての 支えを配置換えする必要がある，進歩に関する 知識伝達だけでは無意味でさえあるととが理解 されよう。

さて，具体的に，どのような進歩があっで 
どのような対処が望まれるか以下考えてみる.

\section{4 . 検査上の進歩とその定着のために}

聴覚検查に打ける進歩は, あまりにあ著し い，その具体例を一つ一つ評価するのは，本文 の目的であないので，省略するが，聴覚検査の 根本といわれる純音の気導・骨導閾值検査が, 実地臨床上では，必ずしも常に満足におてなわ れてはいない.

その理由は沢山ある．乙れを必要と考えられ る患者の数が多く，多忙な医師は，乙れをすべ ての患者におこなう時間的余裕がない，心理的 検査であるために，しばしば反復再検を要す る. 骨導闇值測定には，技術的困難を伴うこと が多く，経験十分な検査技術者が望まれる，等 々.

気導骨導の検査, 語音明膫度の検査など幾つ 汃の検査は，耳科臨床にとって基本的なこと で，明らかに何れのクリニックにも 1 名以上の 検查技師の配置が必要なのである.

平衡機能検査の進歩は，まず $\mathrm{ENG}$ の出現に より，いまはコンピューターによって，多くの あいまいさが除かれて，他覚的定量検査が現実 のものとなりつつある. 平衡機能検查は, 大学 やその他の大病院でおこなえればよいのではな いか，との議論がある。しかし，で存知のよう に，めまいや平衡障害の患者の数は多く，しか
あ，診断上必要な所見の多くは，両三日のうち に変化し，あるいは消退するととが少なくな い，その意味では，大学よりも，むしろ第一線 のクリニックに，多少の簡略化はあっても，十 分に診断能力のある機器の設備が望まれる. 2 , 3 のクリニック協同での設備でよいかむ知れな いが，技術者は 1 名是非必要であろう.

視神経を除いて，脳神経に関する診断は，す べてが耳鼻咽喉科のレパートリーの中にある. したがって, 脳幹機能の検査は, 当然, 耳鼻咽 喉科が中心になっておてなうべき領域である。 各種の平衡機能検査のほかに, 聴性脳幹反応 brain stem responses， あぶみ骨筋反射の検 查, 顔面筋, 咬筋, 喉頭筋などの筋電図, 嗅覚 検査, 味覚検査, 與下機能, 呼吸機能検査など 数多くの定量的，半定量的検查がある. これら は，他科の人々にはおてないにくい検査が多 く，しかも臨床上の価値は大きい。乙れらはみ な，耳鼻咽喉科医によって開発されたのに，実 地臨床への応用は十分であるとはいえないので はなかろうか。これらの検査の多くは，一部の 大学や一部の人々によって，いわば研究と関連 しておてなうといった現状にあると思われる。 これらの検查は，医師が自らおてなうべきもの

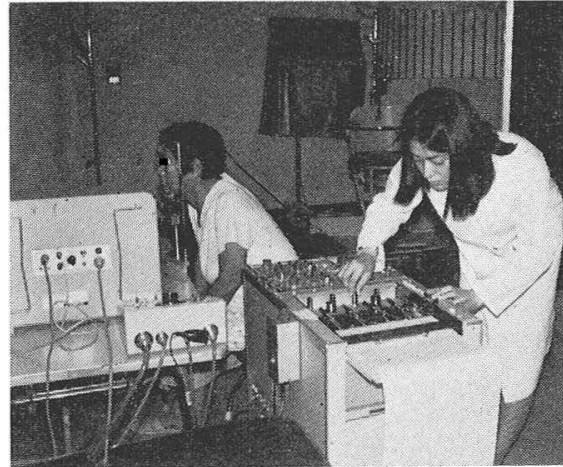

(A)

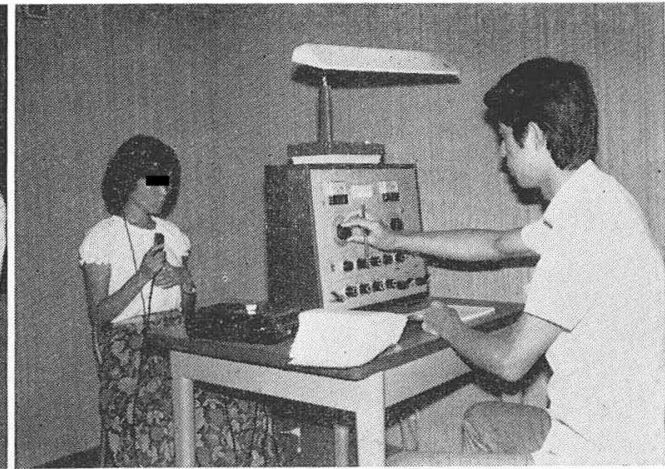

(B)

図 I 平衡機能検查(A) と聴力検査(B)

定量的検査が，エレクトロニクスを用いた機器を駆使しておてなわれる. 専門の検査技師が必要である. 
が多い。むちろん必要な機器や技師屯要求され る.

音声言語機能の検查は, その重要性にも拘ら ず，大学に求いてさえも，乙れを十分におてな っている所は少いのではないか，聴覚との関連 において，言語機能の検查は，とくに幼小児を 対象としての重要性が認識されている。 ヒトと 動物の差は，言語能力の有無にあるととから 屯, 本検査を一部の専門の研究者ないし, 一部 の大学などだけでおてなう状態は望ましくな い. より多くの医師に加えて, 多数の speech pathologist の参加が必要である. 機器のほか に，検査室がいくつ屯要求される。

以上, 検査の進歩と臨床の定着を概括しただ けでも，残念なことに，その大部分は，真に臨 床に定着しているとは云いがたいととである. 定着が不必要なはずは毛頭ない，定着が必要で あれば，その必要性を実現する努力が不足して いるとととなる。このような定着への努力は， 医師自身の能力の拡大だけでなく, 設備, 技師 の配置など, 臨床の規模の拡大にあるととはす ちろんである.

\section{5. 手術 : 進歩と定着, 相対適応の有効な実施, 医療事故の回避}

耳鼻咽喉科領域に戈ける手術の進歩は, 抗生 物質, 手術用顕微鏡, 形成外科的諸手技, 内視 鏡などの進歩に負うている. 鼓室形成術, 内耳 手術, 顔面神経の手術など, 耳科領域における 進歩は著しい，喉頭の機能外科は，外傷や悪性 腫瘍に関連して進歩した。頭頸部外科は，悪性 腫瘍の放射線, 化学療法との統合に书いて, 刮 目すべき進歩を遂げた。

これら手術上の進歩は, その需要との関係か らみて，第一線のクリニックが，す心゙て沶てな う必要はないかも知机ないが，大学ないし大小 の病院には，生命や機能に直結する重要性に鑑 みて，正しい技術が定着すべきである.
これらの手術には，少くとも 2 人以上の医師 の協力が必要であるから，技術を心得た医師の 複数の配置が要求される.

難しい, 多数例の経験を要する手術は, それ を專門におてなう小数の医師のみがおこなうべ きであるとする考えは正しいかあ知れない。し かし，上にあげた手術の中には，かなり多数の 症例を対象之する屯の屯あるし, 少数の専門家 といっても, その協力者, 後継者の養成は, 常 時おてなう必要がある.

手術, 手技の進歩は, 乙机をりり多くの人々 が怙こなうことになると，その創案者が考えあ 及げない，いろいろな結果や副障害の発生を伴

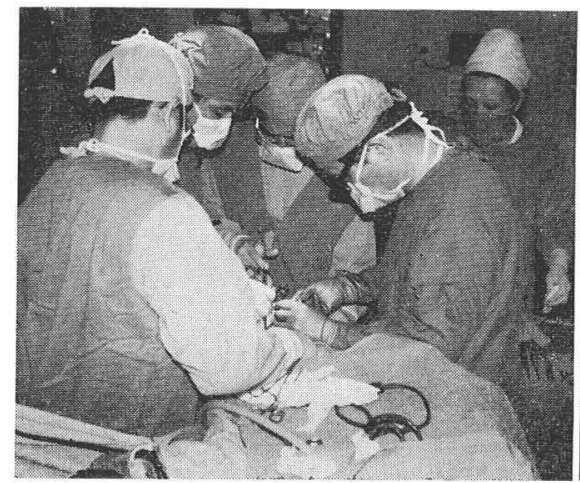

(A)

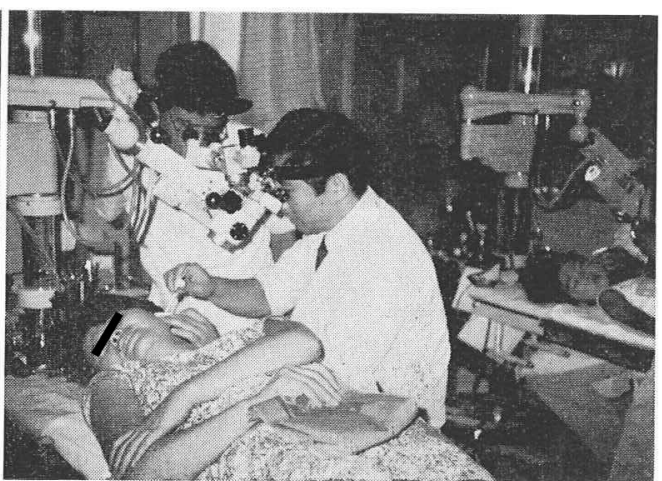

(B)

図 2 頭頸部の手術(A)と外来における耳処理(B) 一般外科と異なった瀻細な手術が多い。とくに，耳については，診断・処置・手術何れにも手術用顕 微鏡を欠くことはできない。 
うことになる。すなわち, 進歩を, 広く臨床に 定着させるためには，手術手技の一般化のため のスタンダードを決めると同時に，手技の指導 と, 細かい注意をつけ加える必要がある.

学会会場での短時間のスライドや，口頭の発 表だけをあとに，困難な手術が誤りなく誰にで あおてなえる筈はない，個人的には，手術見学 など詳細な指導を受ける努力がなされてはいる が，手術を実地に括てなっている人々すべての 心得となっているかどうか・てれは主として医 師自身の問題であり，また，大学人の姿勢の問 題であある。

手術については，別に大きな問題がある．今 日のわが国の医療システムにおいては，とくに ソロ・プラクティスの医師には，手術を実施し にくい条件が揃っていて，現実，とくに都市地 区では，それらの医師による手術件数が激減し ている．手術適応症例が減少しているのでない のは明らかである。病院や大学へ送られる症例 のほかに，手術をした方がよいと考えられる数 多くの例が存在する筈である.

ひと昔前と異なって，今日，当科の症例の大 多数は，慢性疾患患者である。手術は，したが って，今，急いで。というのではなく，適当な 時期に，方法むよく考えて。といったものが多 い.放っておくことあできる。しかし，それら の症例は，手術によれば，明らかにその不都合 加ら永久に解放されるし，毎日の通院む不必要 となる症例かも知れないのである。乙れら，い わば， relative indication による手術症例が，
之くに，わが耳鼻咽喉科領域には数多く，それ らを適切に手術することによって，当科の評判 の向上も期待されるであろう。

手術的治療には，いま一つの問題がある。耳 の手術, 副鼻腔手術, 扁桃手術などに伴う不慮 の事故ないしは副損傷の問題である．困難な手 術手技, 術者の未熟, 不可避的発生が主な原因 と考えられる．乙れら 3 つの原因のうち，前 2 者によるあのは，人為的に克服できる筈であ る. 手術的治療を抑制する理由がての手術に伴 う副損傷であるとすれば，その克服には全力を 挙げるべきで，有用な手術治療を回避すべきで はない.

いわゆる医療事故について㹥，むちろん事故 対策あ必要であるが，根本的に発生を防止する ことが先決である。ごく稀にしか存在しないは ずの副損傷が，意外に多発するとすれば，原因 を究明して，対策を講ずるべきである，すなわ ち, 手術の問題は, 一つは教育修練の問題に帰 すると考えられる。

以上，当科の手術に関連した $3 つ$ 問題につ いて述べた。臨床科に要求されるのは治療であ り，その成功はその科目の振興につながるとと は明らかで，耳鼻咽喉科㡣療上重要な手術が， 大学や大病院のみにおいてしかおてなわれない 現実には，何らかの修正が必要である。ソロ・ プラクティスや，健保制度など，システムに制 約があるとすれば，乙れらをまず改める必要が ある。

\section{6. ハビリテーション・リハビリテーションの定着について}

難聴児に向けての聴能訓練，言語治療は，と くに重要なハビリテーションの領域である。適 切な時期と方法とが設定され，確実に正しく実 施されなくては，乙のハビリテーションは無効 である。

言語発達は，聴覚に依存しているので，聴覚 の全体像を把握するため, 多くの検査が反復し て実施される．根気のいる，時間のかかる仕事
である。そして，鑑別診断が正しくおてなわれ る必要がある。

小児本人にとって必要なのは，しかし，次の ステップである，難聴の原因が明らかとなった とき, 手術か, 補聴器か, 訓練か, それらが適 切に組み合わされ，観察，検查，訓練が実施さ れ，フィードバックされ，はじめて，それらの 方法の有効性が証明される。 

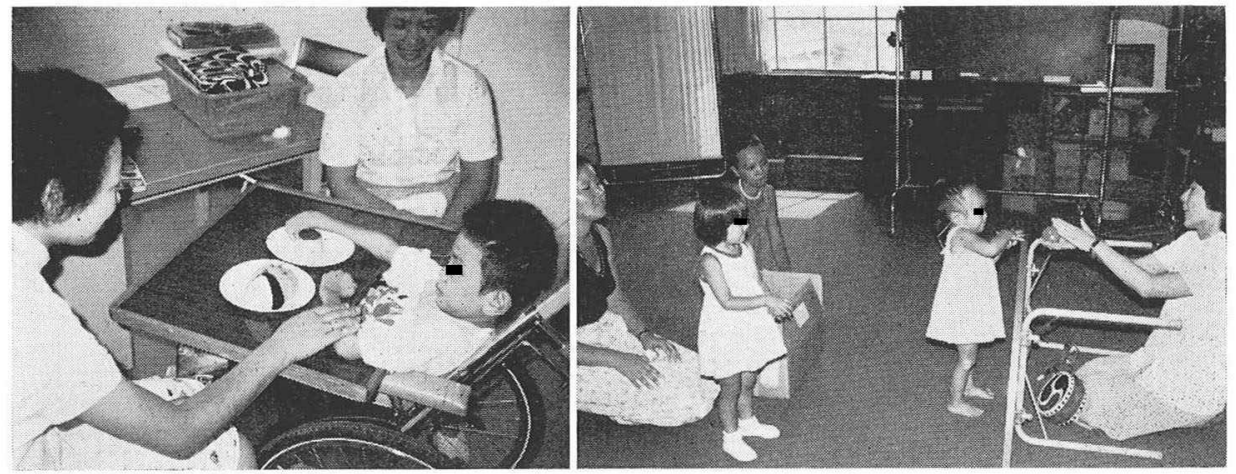

図 3 難聴児のハビリテーション

聴力とそれにつながる言語は，人間社会のもっとも重要な要素として，耳科に関連するハビリテ ーションが注目される. 専門のスタッフが欠かされない。

中途失聴者にたいするリハビリテーションむ 重要である．難聴の程度もいろいろなので，方 法論的にあ各様である.てれらの人々にたいす る適切な指導者や訓練機関が，数において，ま ず全く不足している.

音声・言語障害者の訓練も，多くの場合，あ る程度の方針が決まると，説明があって，その 後は, 多くの場合患者の自主的努力にまかされ る.ただ努力がなされれば達成できるような簡 単なととではないはずなのに，経過を追って指
導するのに必要な人やシステムが欠如してい る.

リハビリの臨床定着のためには，人の配置や システムの確立が必須である. 従事する人とし ては，スピーチ・テラピストのほかに，OTあ るいはMSWといった社会復帰関係の多くの人 々が要求される．医師には，乙の方面の問題意 識, 問題解決に十分な知識と意欲とが必要であ る. そして，医学と訓練，教育を有機的に関連 づける役割りが課せられることとなる.

\section{7 . 必要な診療実施のための 3 方策一一教育的アプローチ，医療経済的アプローチ， 医政的アプローチ}

以上, 耳鼻咽喉科の 3 つの領域，検査診断， 手術, リハビリデーションについて，何が求め られ，何がおてなわれ，何がおこなわれていな いかなど概観してみたが，とのような問題は， 当然, 耳鼻咽喉科に限られたととではない.

学問的華かさに蔽われた現実の医療の質が問 題である，わが国の耳鼻咽喉科学は，世界的水 準にあると思うが，その水準は臨床に十分に定 着していないし, そのための努力も甚だ不十分 である．対策が必要である．国民のニーズが, いわば無視されている心配がある.

本問題の対策には， 3 つ, 教育的アプローチ 医療経済的アプローチ，医政的アプローチがあ
って，何れも同程度に重要である。

検査，診断技術の定着のためには，大学にお ける卒前教育カリキュラムへの盛り込みが, む っと要求されてよいであろう．卒後ないし生涯 教育については，講演会などはあまり有効でな く，日時をかけた実技講習が必要である．專門 の検査技師の養成とともに，医師には，結果の 読解力と指導力とが必要とされる.

手術に関する教育的アプローチには，臨床医 すべての生涯的努力による教育訓練が必須であ る. 手技的進歩には，一般化のための努力が, 同時に, よりつよく必要とされるわけで，容易 な新法の実施は，つよくいましめられる。しか 
し，より良い方法の採用は常に速かにおこなわ れるべきであり，外科的方法論実施上の基本へ の留意が, 医師すべてに要求される所以である. ハビリテーション，リハビリテーションの定 着のためには，まず卒前卒後の教育カリキュラ ムに，大幅に本問題をとり入れる必要がある. 医師の開眼が第一に必要である.リハビリテー ションは，狭義の医療と密接に関連があるのに あ拘らず，大学の教育カリキュラムに占める時 間数は極めて小さい．乙の方面に明るい教育者 がそしいととが，その原因の一つであろう。大 学の責任者の注意を換起したい。個々の臨床科 目には，また，それぞれリハビリ領域があるは ずで，科目ごとのカリキュラム編成に際しての 配慮が望まれる.

以上の教育的アプローチは，あちろん根本で あるが，同時に，医療経済的配慮がなくては， 何れの名案む現実のむのとはならない．検査， 手術，リハビリの何れをとっても現在のシステ ムには不都合が多く，とくに人員の配置，シス テム，報酬制度などに改革すべきととが多い。

大学，病院，クリニックと，それぞれに異な った，しかむ大事な機能が，乙れらの領域に求 るめられととが明らかである以上，それを実現 するための方策が具体的に求められる。ずて の医師の意識刷新が，このためには要求される のであろう.

図 4 亿示したのは，医療の根本的骨組みであ って，乙の何れかの部分に不都合があると，現 実の医療にひずみが生じてくる. Social needs は，社会の変化に伴って，徐々に，あるいは 急速に変るあのであるから，それに伴って， medical care あ変化する必要がある. Medical

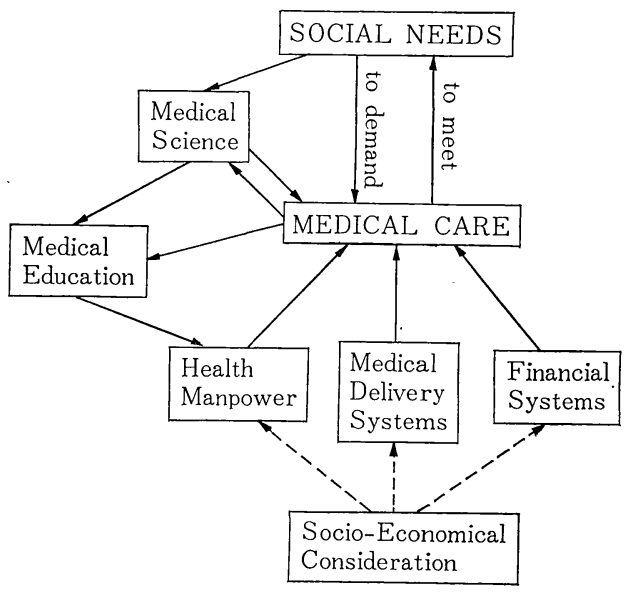

図 4 医療を支えるシステム

science は, medical care を支える重要な柱 の一つであるが，しばしば， science 自身の autonomy のために，現実加ら浮き上るよう である。

Medical care は，医師教育を充実すれば十 分と見られ勝ちであるが，今日，医療に従事す る manpower は, 各種多様の領域にわたり, 医師は，リーダーであるにしても，その一部を 分担するに過ぎない。

また， medical care を支えるのは，乙のほ かに, system と経済とがあって，誰あとれら を軽くみるわけではないが，その変革が常時必 要であるという重大な事実の認識が，とくに医 政関係に要望される。一大改革は，むしろ必要 でなく，常に小さな手直しや修正が必要であ る.そのような小さな修正は, 現場の needs に立脚した feed-back を基盤にすべきで，て こにも，それを可能にするようなフレキシブル なシステムの導入が望まれる。

\section{8. おわりに一一耳鼻咽喉科発展のために，一つの意識変革が必要では？}

武田信玄の「ヒトは城」ではないが，耳鼻咽 喉科ないし耳鼻咽喉科学が，より発展を遂げる ためには，現状を直視し， needsに立脚した変 革を志向した多くの人々の存在が必要である. 教育には，大学に拈ける卒前教育，大学や病
院における卒後教育，学会や医師会などの主催 する生涯教育，個人の自らおこなう自己研修な ぞがあり，それぞれ異った重要性が認められ る.

卒前教育については，秀れた人材をわが領域 
に導く意味も含めて，別の意義があり，カリキ嗃因をとり除く必要がある.

ユラム編成とその実施については，ビジョンに 社会的ニーズは，年々変化し，それに対処す あとづいた慎重さが望まれる。

臨床科を支えるのは，臨床上の実績である． る医療も，つね注歩し変化する。との両者を 有効に結びあわすためには，常時，教育的，医 診断, 治療, リハビリという 3 つの重要な領 療経済的，それに医政的配慮が望まれるわけ 域，それぞれについて，わが科目は十分に成果 をあげているであろうか。 また，それがあし不 十分であるとすれば，原因は何であろうか.

「なすべきととをなす」という，でく当然のと で，それらのうち何れが欠けても，適切な医療 を実施することはむずかしい。

以上，今日の，そしてそれに連続する明日の

とが，あしおてなわれていないとすれば，その “耳鼻咽喉科を支えるむの”について考察した。 同志諸賢の目に止まれば幸いである。

\section{参考 文 献}

1）鈴木淳一：耳科学臨床とその将来一手術とくに聴 力改善手術について一. 耳鼻と臨床 $23: 771$ 775, 1977.

2）鈴木淳一：医原性状態について。あいみっく 3 ： 原稿到着：昭和 53 年 8 月 4 日 別刷請求先 : 鈴木淳一 